\title{
Dünya Basınında İsrail- Filistin Meselesi: 2021 Mayıs İsrail Saldırılarına İlişkin Haberlerin Söylem Analizi
}

Başvuru Tarihi: 06.10 .2021 Yayın Kabul Tarihi: 22.12 .2021 Yayınlanma Tarihi: $\quad 30.12 .2021$

\author{
Elif Kaya ${ }^{1}$ \\ Selçuk Üniversitesi, iletişim Fakültesi, \\ Gazetecilik Bölümü, Konya \\ elif.kaya@selcuk.edu.tr \\ (iD) ORCID: 0000-0003-4629-6647
}

\section{Öz}

Şiddet ve saldırı olgusu toplumsal hayatta yer alan ve medya aracılığıyla gündelik hayata dahil olan bir konudur. Medyanın kamuoyunu bilgilendirme noktasında saldırı ve terör olaylarına yaklaşımı, saldırı haberlerini ele alış biçimi insanların düşüncelerini etkileme noktasında önemli görülmektedir. Saldırı olaylarının sunuluşu, ortaya koyduğu anlam, insanların saldırılara ilişkin yaklaşımını ve düşüncesini etkilemektedir. Diğer yandan medyanın şiddet olgusunu ele alış biçimi sahip olduğu ideolojiden ayrı düşünülememektedir. Medyada sunulan şiddet ve saldırıya dair içeriklerin aktarılma şekli haberin inşasında ve taşıdığı anlamda ortaya çıkmaktadır. Bu nedenle medyanın saldırı olaylarını aktarırken haberin inşasında üstlendiği rolü çözümlemek haber ve ideoloji arasındaki ilişkiyi görmek açısından önemlidir. Meydana gelen saldırı ve terör olaylarının medyaya yansıması ideoloji ve yayın politikalarına göre farklılık göstermektedir. Medya kuruluşlarının sahip olduğu farklı ideolojik yapılar ve politikalar haberin dili, söylemi ve içeriğinde kendini göstermektedir. Bu çalışmada İsrail'in Filistin'e karşı 10 Mayıs 2021 tarihinde başlayan ve ateşkesin imzalandığı 21 Mayıs 2021 tarihine kadar süren 11 günlük saldırıları aktaran haberler incelenmiştir. Çalışma Al Jazeera, TRT World, Sputnik Haber Ajansı, Al Arabiya ve Haaretz haber ajanslarının 11- 21 Mayıs 2021 tarihleri arasındaki haberleri ile sınırlandırılmıştır. Seçilen haber içeriklerinin saldırıya ilişkin bakış açısı, haber başlığı, içerik ve görselleri Teun van Dijk'ın söylem analizi yöntemi ile incelenmiştir. Çalışmanın sonucunda, ideoloji ve yayın politikası noktasında farklılık gösteren medya kuruluşlarının İsrail- Filistin olayını aktarırken de ideolojilerinin dışında hareket etmediği ve söylemlerini bu doğrultuda inşa ettiği görülmektedir.

Anahtar Kelimeler: İsrail, Filistin, Gazze, haber, ideoloji, söylem analizi.

\footnotetext{
${ }^{1}$ Araştırma Görevlisi
} 


\title{
The Israel-Palestine Issue in the World Press: Discourse Analysis of the News Regarding the May 2021 Attacks
}

Application Date: 06.10.2021 Accepted Date: 22.12.2021 Publishing Date: 30.12 .2021

\author{
Elif Kaya ${ }^{2}$ \\ Selçuk University, Faculty of Communication, \\ Department of Journalism, Konya \\ elif.kaya@selcuk.edu.tr \\ D ORCID: 0000-0003-4629-6647
}

\begin{abstract}
The phenomenon of violence and attack is an issue that takes place in social life and is included in daily life through the media. The media's approach to attacks and terrorist incidents at the point of informing the public, and the way it handles the news of attacks are considered important in terms of influencing people's thoughts. The presentation of the attacks and the meaning they reveal affect people's approach and thinking about the attacks. On the other hand, the way the media handles the phenomenon of violence cannot be separated from media ideology. The way in which the content about violence and attack presented in the media is conveyed emerges in the construction and meaning of the news. For this reason, it is important to analyze the role of the media in the construction of the news while conveying the attack events to see the relationship between the news and ideology. The reflection of the attacks and terrorist incidents on the media differs according to the ideology and broadcasting policies. Different ideological structures and policies of media organizations show themselves in the discourse of the news. In this study, the news about Israel's 11-day attacks against Palestine, which started on 10 May 2021 and lasted until 21 May 2021, when the ceasefire was signed, were examined. The study was limited to the news of Al Jazeera, TRT World, Sputnik News Agency, Al Arabiya, and Haaretz news agencies between 1121 May 2021. The perspective, news title, content, and visuals of the selected news contents were examined by Teun van Dijk's discourse analysis method. As a result of the study, it is seen that media organizations that differ in terms of ideology and broadcast policy do not act outside of their ideologies while conveying the Israel-Palestine incident and build their discourses in this direction.
\end{abstract}

Keywords: Israel, Palestine, Gaza, news, ideology, discourse analysis.

\footnotetext{
${ }^{2}$ Research Assistant
} 


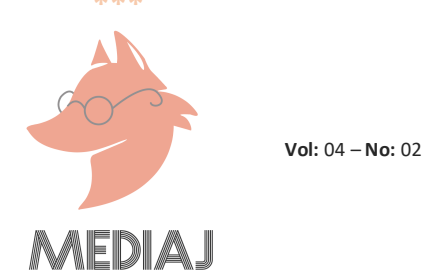

\section{GíRiş}

İsrail- Filistin geriliminin zemini, İsrail'in Gazze'yi abluka altında tutması ve farklı dönemlerde ağırlıklı olarak saldırılarına devam etmesine dayanmaktadır. İsrail- Filistin çatışmalarına ilişkin tarihsel arka planda terör, şiddet, saldırı, ölüm gibi sonu bitmeyen sorunlar yer almaktadır. İsrail'in Gazze'ye karşı farklı yıllarda gerçekleştirdiği hava saldırıları ve Mescid-i Aksa'da Müslümanlara uyguladığı şiddet, olayların giderek artmasına neden olmuştur. İsrail ve Filistin arasında yaşanan ve çözüme kavuşturulamayan gerilim 2021 Mayıs ayında İsrail'in yoğun hava bombardımanı ile farklı bir boyuta geçmiştir. 2021 Mayıs ayında Şeyh Cerrah Mahallesinde başlayan ve devamında Mescid-i Aksa'da Müslümanlara karşı saldırılara dönüşen olaylar 9- 10 Mayıs günü şiddetini artmıştır. 10 Mayıs tarihinde Ramazan ayında, 'Kudüs Günü' kutlamalarında toplanan İsrail vatandaşları, Mescid-i Aksa'dan Müslümanların çıkarılması için çağrı yapmış ve ardından olaylar başlamıştır. Tırmanan olaylar karşısında İsrail, Gazze Şeridi'ne hava saldırısı gerçekleştirmiş ve Hamas (İslamî Direniş Hareketi) roket atışı ile karşılık vermiştir.

Yaşananlar karşısında Birleşmiş Milletler Güvenlik Konseyi ateşkes ilan edilmesi için çağrıda bulunmuş ancak bu çağrılar İsrail tarafından reddedilmiştir. 11 gün süren saldırılar 21 Mayıs günü Katar, Mısır, ABD ve Birleşmiş Milletlerin aracılığıyla imzalanan ateşkes ile son bulmuş ve İsrail saldırıların durdurulmasını kabul ettiğini bildirmiştir. 21 Mayıs gece saat 02.00 'da ateşkesin başladığı resmi şekilde duyurulmuştur. Açıklanan verilerde İsrail'in gerçekleştirdiği saldırılar sonucunda 10 Mayıs'tan itibaren 65'i çocuk, 39'u kadın 232 Filistinlinin hayatını kaybettiği; şehrin birçok noktasının, okul, hastane gibi kurumların hava saldırısı sonucunda harabe haline geldiği belirtilmiştir.

Filistinlilere uygulanan orantısız şiddet dünya basınında geniş yer bulmuş ve dünyanın birçok yerinde İsrail'in gerçekleştirdiği saldırılara ilişkin protestolar düzenlenmiştir. 21 Mayıs günü başlayan ateşkese kadar geçen 11 günlük süreçte İsrail'in hava saldırıları Gazze'de çocukların çoğunlukla olduğu 200'ün üzerinde ölüme neden olmuş ve yaşanan olaylar medya kuruluşlarında farklı açılardan ele alınmıştır. Bu doğrultuda Al Jazeera, TRT World, Sputnik Haber Ajansı, Al Arabiya ve Haaretz medya kuruluşları örneklem olarak seçilmiş ve bu gazetelerin internet sayfalarında 11.05.2021- 21.05.2021 tarihleri arasında yayınlanan haberler analiz edilmiştir. Çalışmada birbirinden farklı yayın politikası ve sahiplik yapısı olan medya kuruluşlarının İsrail'in Filistinlilere yönelik saldırılarını haberleştirmesi ideoloji ve söylem pratikleri çerçevesinde incelenmiştir.

\section{MEDYADA ŞIDDET: SALDIRI HABERLERI}

Şiddet, nötr haldeki gücün farklı şekillerde aktif hale gelmesi olarak tanımlanmaktadır. Şiddet, baskı, zorlama ve fiziksel eylemlerle ortaya çıkmakta, kişi, nesne veya mekânı deformasyona uğratmaktadır (Ünsal, 1996; akt. Öner, 2016, s. 607). Kovel (1996, akt. Arslan, 1998, s. 2), şiddetin yok edici özelliğine vurgu yaparak "Şiddet bir ihlal, yani diğer bir varlığın bütünlüğünün sekteye uğratılması anlamını içerir. Sevilmeyen bir çocuk, yurtları İsrail devletince gasp edilmiş olan Filistinliler, polisin terörüne maruz kalan getto sakinleri, kapitalist üretimin kendi işgüçlerine yabancılaştırdığı işçiler, asit yağmuru altındaki ormanlar, hepsinin varoluş koşulları ihlal 


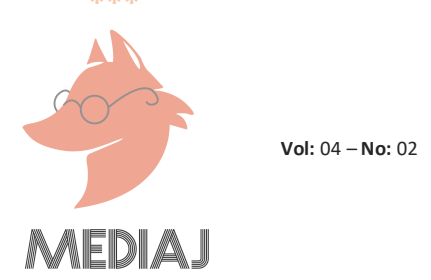

edilmiştir." ifadeleri ile şiddeti ayrıntılı bir şekilde açıklamaktadır. Arıkan (1987, s. 73; akt. Arslan, 1998, s. 3) ise şiddeti "Şiddet saldırganlığın bir biçimidir. Başka bir deyişle, yıkıcı yok edici saldırganlıktır. Kişilere ya da çeşitli nesnelere fiziksel zarar vermeyi içermektedir. Şiddet, güçlü, kontrolsüz, aşırı, birdenbire ve bazen de amaçsız olabilir." ifadeleriyle tanımlamaktadır.

Michaud (1994, s. 5-6), şiddeti cinayet, işkence, darbe, etkili eylem, savaş, baskı, suçluluk ve terörizm olarak tanımlamaktadır ${ }^{3}$. Şiddet olgusunun temelinde yatan doğal güç, değer yargıları kaybolduğu ve yerini vasıfsız bir güce bıraktığı için şiddete evrilmektedir. Bu şekilde belirli ölçüleri aşan veya düzeni bozan güç 'şiddet' olarak adlandırılmaktadır. Karşılıklı ilişkinin var olduğu bir ortamda taraflardan birinin doğrudan veya dolaylı, toplu veya dağınık olarak diğerlerinin bedensel, ahlaki, moral bütünlüğüne, mallarına veya simgesel, kültürel değerlerine zarar veren davranışlar olarak tanımlanan şiddet (Michaud, 1994, s. 8), bir amaca ulaşmanın aracı işlevi gördüğü gibi amacın sonucunu da oluşturabilmektedir. Şiddet aynı zamanda sonuçları dikkate alınmadan gerçekleştirilen eylemlerin nedeni de olabilmektedir (Küçük Durur, 2017, s. 47).

Bir durumu şiddet olarak tanımlayabilmenin iki temel öge ile mümkün olduğunu belirten Gümüş (2006, s. 15), güç bulundurma potansiyeline sahip olmak ve zarar verme, engelleme gibi zorlama/zorbalık içeren eylemlerin şiddeti meydana getirdiğini ifade etmektedir. Neyin şiddet olarak nitelendirilebileceğini şiddetin aktör/kurban/tanık ilişkisi üzerinden detaylandıran Riches (1989, s. 21-22), şiddet eylemlerinin tanımlanmasında farklı toplum ve kültürlerde de olsa zorluk yaşanmayacağını belirtmektedir. Bu doğrultuda Riches şiddeti, sosyal ve kültürel kaynak olma niteliği üzerinden kültürlerarası geçerliliği olduğunu belirten dört özelliği açıklamaktadır:

- Şiddetin uygulanması, meşruluk sorunu üzerindeki mücadeleye bağlıdır.

- Bir şiddet ediminin uygulanışında yer alanlar veya bir şiddet görüntüsünü izleyenlerin temel düzeydeki kavrayışları arasındaki fark muhtemelen az olacaktır: Kilit anlamında 'haklılığı tartışmalı bir zarar verme' olarak şiddetin yanlış anlaşılması hiç de muhtemel değildir.

- Şiddet uygulaması duyular için son derece hissedilirdir.

- Şiddetin ılımlı bir etki derecesinde kullanımı, özel aletler veya gizembilim bakımından görece pek az donanım gerektirir. İnsan bedeninin gücü ve bu imkanların fiziksel nesneleri tahrip edebildiğini bilmek bir başka insana karşı asgari ölçüde başarılı bir incitme eylemini gerçekleştirmek için yeterlidir.

Şiddetin gücü, pratik anlamda araç olma ve kendini ifade anlamında sembolik olma özelliklerinden kaynaklanmaktadır. Şiddet, bireyleri ve sosyal çevreyi dönüştürme aracı ve önemli görülen sosyal fikirleri ortaya koyma bakımından etkisi bilinen bir olgudur (Riches, 1989, s. 22). Şiddet olgusu tarihin her anında her toplumda varlığını devam ettirmiş ve bütün insanlık için sorunların kaynağını ya da sonucunu oluşturmuştur. Bu noktada Riches'ın şiddetin her toplumda ve kültürde etkili olduğunu belirtmesi şiddet olgusunun gündelik hayata ve toplumsal pratiklere nasıl yerleştirilmiş olduğu veya görünür kılındığının önemini ortaya koymaktadır.

${ }^{3}$ Michaud şiddet kavramını bir yandan gerçekleşen olgular ve eylemler diğer yandan gücün, duygunun varoluş üslubu üzerinden açıklamaktadır. Olgu ve eylemleri içeren şiddet huzur kaçıran, düzen bozan; gücün üslubunu içeren şiddet ise ölçüyü aşan ve kuralları çiğneyen kaba gücün yönünü göstermektedir. 


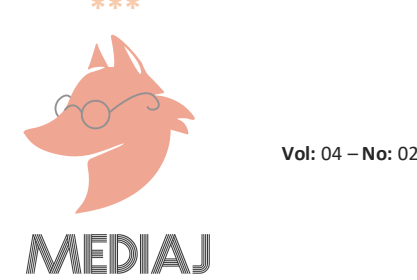

Şiddet olgusu yüzyıllar önce hikâye anlatımının önemli bir parçasını oluşturmuştur. Şiddet olgusunun insanlık tarihine ve kültürüne yerleşmiş olduğunu ifade eden Trend (2008, s. 10), şiddet temalarının birçok ulusun mitolojisinde, dini öğretilerde, edebiyat ve sanat eserlerinde yer aldığını belirtmektedir. Şiddet unsurları ahlaki derslerin konusu olmuş, insanlık tarihinin betimlenmesinde kullanılmış, zaman zaman insanları sınırlandırmak zaman zaman ise korkutmak için kullanılmıştır. Bu doğrultuda günümüzde şiddet unsurlarını insanlara ulaştırmak kitle iletişim araçları ve teknoloji ile daha da kolaylaşmıştır. Medya ve internette yer alan şiddet içeriklerinin artması, şiddet kavramını gündelik hayattan bağımsız bir şekilde düşünülmesini zorlaştırmıştır.

Hikâye anlatımında şiddet unsurunun kullanılması dini, edebi ve mitolojik metinlere dayansa da kitle iletişim araçlarının ortaya çıkması ile şiddet sinema, televizyon ve internette fazlasıyla yer almaya devam etmiştir. İnsanlar gelişen olayları bilme ve dünyadan haberdar olma isteğini kitle iletişim araçlarından edindikleri bilgiler ile gidermektedir. Toplumun bilgilenmesinde medya güçlü bir araç olmasının yanı sıra sunduğu imge ve görüntüler ile bireylerin düşünce biçim ve tutumlarını etkileyebilmektedir (Palabıyıkoğlu, 1997, s. 123). Medya, olayları haberleştirirken kendi yayın politikasına ve çıkarlarına uygun şekilde içeriği kurgulayarak sunmaktadır (Zorlu, 2016, s. 15). Kamuya haber ve bilgi vermekle sorumlu olan medya (Çakır, 2007, s. 39), izlenirliğini ve okunurluğunu arttırmak için haber değer etmenlerinden olumsuzluk ve şiddet unsurlarından da yararlanmaktadır. Şiddet unsurlarını barındıran içerikler habere olan ilgiyi arttırmaktadır (Küçük Durur, 2017, s. 50).

Terör ve saldırı haberleri trajedi, kan, tehlike ve güncellenebilir olması gibi barındırdığı ögelerle izleyici/ okuyucuların dikkatini çekmekte ve kitleler tarafından tüketilmektedir. Diğer yandan haber değer etmenlerinden olumsuzluk ve kötü olaylar insanların daha çok dikkatini çekmekte ve birçok habere göre şiddet içerikleri daha çok tercih edilmektedir. Medya kuruluşları da insanların taleplerine yönelik olumsuzluk içeren haberleri yoğun olarak yayınlamaktadır. Çok sayıda kitlelere ulaşmak ve izlenirliğin artmasını sağlamayı hedefleyen medya için terör ve saldırı haberleri bir aracı oluşturmaktadır. Medya, toplumun terörizm ve saldırı gibi toplumsal problemler karşısında ne düşüneceğini belirleyen güçlü bir etkiye sahiptir. Bu doğrultuda terör ve saldırı haberleri de kitlelerin üzerinde etkili olmanın yollarından birini oluşturmaktadır (Avşar, 2017, s. 122). Medyanın etkisi göz önünde bulundurulduğunda sunulan şiddet içerikli haberlerin, bireylerin şiddet olgusuna karşı düşüncelerini etkilediği belirtilmektedir (Palabıyıkoğlu, 1997, s. 124).

Kitle iletişim araçlarında yer alan şiddet içerikleri, her yaştan insan tarafından tüketilmekte; medyada yer alan savaş, terörizm ve suç içerikleri şiddetin gerçekliğini arttırmaktadır (Trend, 2008 , s. 10). Özellikle bilgi ve iletişim teknolojilerindeki gelişmeler, çevrimiçi oyunlar, sosyal medya platformları dijital ortamda bilgiye kolay erişim sağlamanın önünü açmıştır. Bu şekilde insanlar bombalama, patlama, cinayet vb. şiddet unsurlarını barındıran görüntülere daha çok maruz kalmaktadır. Medyada sunulan şiddetin yaygınlığı toplumun şiddet karşısında duyarsızlaşmasına ve şiddeti gündelik hayatın sıradan bir parçası olarak algılamasına neden olmaktadır (Zorlu, 2016, s. 28).

Medyada yer alan şiddet içeriklerinin insanları şiddet dolu bir dünyada yaşadıklarını düşündürdügünü ve bu nedenle medyanın güvenliği sağlamak adına şiddetin varlığını aktardığını 


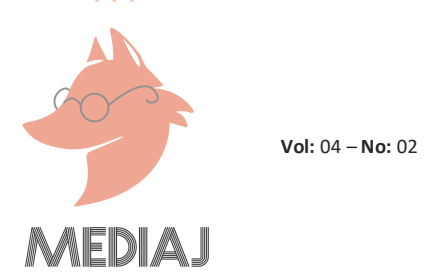

belirten Trend (2008, s. 80), medyanın şiddet sunumunun insanların gündelik hayatını birçok yönden etkilediğini vurgulamaktadır. Medyanın sunduğu şiddet içerikleri ile korku kültürünün oluşturmasında 11 Eylül saldırısının önemli bir etkisi vardır. Amerika Birleşik Devletleri'nde gerçekleşen 11 Eylül saldırısı ile şiddete dayalı eylemler dünya genelinde konuşulmaya başlanmış ve şiddet olaylarının insanlığı tehdit ettiği düşüncesi yükselmiştir. Bu durumun sebeplerinden biri olarak Amerikan medyasının, dünya genelinde yaşanan saldırıların insanlık için tehdit oluşturmadığını düşünürken Dünya Ticaret Merkezi'ne yapılan saldırıya gösterdiği ilgi ile saldırının küresel bir gündem haline gelmesi gösterilmektedir. Medyanın 11 Eylül saldırısına ilişkin haberleri ele alma ve sunma biçimi artık şiddetin küresel bir sorun haline geldiğini göstermekte iken şiddeti önlemeye yönelik yürütülecek politikaların da zeminini oluşturmaktadır (Cirhinlioğlu, 2004, s. 8).

Medyanın gerçekleşen şiddet olaylarını ekranlara getirmesi, gazete sayfalarına taşıması ile şiddet ve şiddete ilişkin ayrıntılar insanlara ulaşmaktadır. İnsanlar, gerçekleşen saldırıların ardından daha önce var olmayan bir aciliyet duygusu ve merakla kitle iletişim araçlarına yönelmekte (Trend, 2008, s. 96), medyada sunulan şiddet içeriklerini tüketerek şiddeti özümsemektedir. Meydanın şiddeti, gündelik hayatın bir parçası ve sıradan bir olay olarak sunması insanları şiddet unsurlarına alıştırmakta ve duyarsızlaşmanın önünü açmaktadır. Şiddete ilişkin duyarsızlaşma arttıkça şiddet dozunu arttırarak büyümekte ve normalleşmektedir (Uysal, 2006, s. 124).

Basın kuruluşlarından ve medyadan beklenen terör ve saldırı haberlerini sunarken etik değerleri göz ardı etmeden yaşanan saldırı olaylarıyla demokratik sistemin zarar gördüğünü belirtmeleridir. Medya bu doğrultuda terör eylemlerinin meşru ve demokratik yollardan gösterilecek kamuoyu tepkileri ile önlenebileceğini vurgulayan yayın politikasını benimsemelidir. Medyanın sahip olduğu güç, terör eylemlerine ilişkin yaşanan sorunların çözümünde önemli bir rol oynamaktadır (Avşar, 2017, s. 124).

Medyanın saldırı haberlerinin sunumuna ilişkin sergilemesi gereken davranış yalnızca olayları, gelişmeleri aktarmak değil aynı zamanda güçlü bir etkiye sahip olduğunu bilerek etik ilkeleri ihlal etmemesini de içermektedir. Bassiouni (1982, s. 140-141), terör ve saldırı haberlerinin sunulmasında medyanın göz önünde bulundurması gereken noktaları açıklamakta ve medyanın kamuyu bilgilendirme işlevini vurgulamaktadır:

- Medya özellikle teröristlere istihbarat sağlayacak bilgileri ve olayları alevlendirecek ayrıntıları vermeyi geciktirmelidir.

- Gerçekleşen terör/ saldırı olayı ile canlı röportajlar ve resmi cevaplar çekicilik ve aşırılık unsurlarını içermemelidir. Doğrulanmamış bilgi ve sayılar gelecekte planlanan olası saldırılar için medyada verilmemelidir.

- Medya, şiddete başvurmanın sosyal değerlere ve yaşama aykırı olduğunu, toplumun şiddet karşısında çaresiz olmadığını belirtmelidir.

Medya, terör eylemlerine ilişkin haberleri sunarken şiddeti sıradanlaştıran ve estetize eden bir yayın anlayışından uzak durmalı, haber dilinin ise dezenformasyon ve manipülasyon içermediğine dikkat etmelidir (Avşar, 2017, s. 124). 


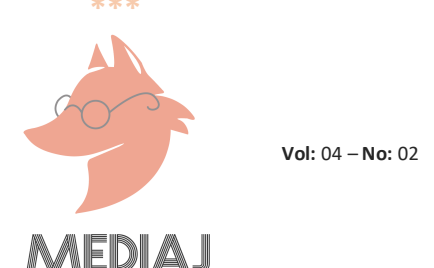

\section{Medyada Irkçı, Ayrımcı Dil}

Tarihin her anında görülen, günümüzde de artarak devam eden 'biz' ve 'ötekiler' temelindeki ayrımcılık, ırkçılık, yabancı düşmanlığı, katliam ve şiddet üzerinden de kendini göstermektedir. Medya açısından bakıldığında ise ayrımcılık ve düşmanlık 'söylem' ile somut hale gelmektedir (Çelenk, 2010, s. 215). Irkçı, ayrımcı söylemin oluşması ve medya aracılığıyla meşrulaştırılmasının temelinde 'ayrımcı ideolojiler' vardır. Toplumsal yapılar içerisinde politik, ekonomik, sosyokültürel açıdan farklııkları, eşitsizlikleri barındırmakta ve sürdürmektedir. Bu doğrultuda işleyişi devam eden toplumsal düzeni korumak adına azınlıkta kalan gruplar, 'ötekiler' dışlanmakta veya marjinalleştirilmekte ve 'biz' söylemi korunmaktadır. Medya ise kullandığı dil pratikleri ve söylem ile var olan farklılıkları, ayrımcılığı derinleştirmekte, meşrulaştırmaktadır (Doğanay, 2018, s. 18). Haber metinlerinde kullanılan dilin ve kurulan söylemin toplumsal gerçekliği inşa etme ve yeniden kurma anlamındaki önemi (Devran, 2010, s. 168), haber içeriklerini üzerinde durulması gereken bir konu haline getirmektedir. Ayrımcılık, ırkçılık söylem yoluyla metin ve konuşmalar üzerinden aktarılmaktadır. Egemen ideoloji ise egemen söylem ile toplumsal ayrımcılık, ırkçılık pratiklerini üretmekte ve yaymaktadır. Bu doğrultuda medya, egemen ideolojinin sahip olduğu iletişim aracı olarak ayrımcı söylemin üretilmesi ve yaygınlaştırılması noktasında etkilidir (Çınar, 2013, s. 138).

Medyanın sözel, görsel ve işitsel kodları kullanarak oluşturduğu içerikler toplumun değer alanına aktarılmaktadır. Bu yolla medyanın kitlelere ulaşma gücü aynı zamanda ırkçı, ayrımcı söylemin toplumda karşııı bulmasını ve yayılmasına neden olmaktadır. Medya tarafından aktarılan ayrımcı söylem ve içerikler, bireylerin gündelik hayatta ayrımcı söylemi nasıl tanımlayacağını ve kullanacağı noktasında hazır kalıplar ve düşünceler üretmektedir (Keneş, 2014, s. 414).

Medyanın kitlelere kolayca ulaşan dizi, film, reklam, haber gibi içeriklerle ayrımcı mesajları, söylemleri iletmesi yoluyla egemen ideolojinin egemen söylemi yaygınlaştırılmaktadır (Çınar, 2013, s. 139). Irkçı, ayrımcı söylem medya aracılığıyla kendine alan oluşturmakta ve topluma ulaşmaktadır. Medyanın kitlelere ulaşma gücü göz önünde bulundurulduğunda ırkçı söylemin kolayca yayıldığı ve insanlar üzerinde etkili olduğu söylenebilir. Çelenk (2010, s. 216), medyanın ırkçı, ayrımcı, nefret söylemini pekiştirdiğini ve bu yolla ayrımcılığın topluma yerleştiğini, insanlar tarafından benimsendiğini belirtmektedir.

Medya, kendi ideolojik konumlanmasına göre haber içeriklerini oluştururken olayları tanımlama ve nitelendirme noktasında ideolojik eğilimini açıkça belli etmektedir. Bir olay 'çatışma' olarak nitelendirilirken başka bir ideolojinin bakış açısı doğrultusunda aynı olay 'katliam' olarak ifade edilebilir. Kişilerin 'terörist', 'sempatizan' veya 'gerilla' olarak adlandırılmasındaki söylem farklılıkları medya kuruluşunun sahip olduğu ve yaymaya çalıştığı ideoloji ile ilgilidir (Devran, 2010, s. 167). Medya gündelik hayatta yaşanan ayrımcılık, ırkçı davranış ve söylemleri yeniden üretmekte, meşrulaştırmakta diğer yandan mevcut ırkçı söylemin varlığını da pekiştirmektedir (Çelenk, 2010, s. 227). Medya kuruluşlarının kendi ideolojilerine uygun olarak inşa ettikleri söylem dinleyici/okuyucular tarafından özümsenmekte ve bu şekilde ayrımcı veya ırkçı söylem haber içeriği ile sınırlı kalmamaktadır.

Medyada yer alan ırkçı, ayrımcı ve nefret söylemine ilişkin çalışmalar medyanın farklılıkları 


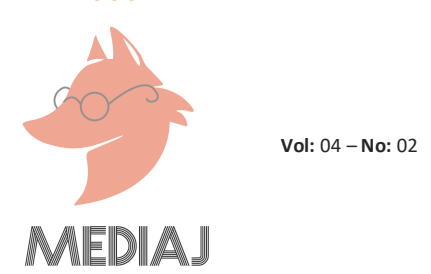

derinleştiren, ırkçılığı ve saldırganlığı meşrulaştıran bir dil kullandığını göstermektedir. 10 Ekim 2015'te Ankara'da gerçekleşen tren garı terör saldırısına ilişkin farklı yayın politikasına sahip gazete haberlerinin makro ve mikro yapıları incelenmiştir. Elde edilen sonuç ana akım gazetelerden Hürriyet, Posta, Sözcü ve Sabah gazetelerinin manşette terör saldırısına az yer verdiği diğer yandan haber dilinde abartma, çarpıtma gibi nefret kategorilerinin kullanıldığını göstermektedir (Tunçay, 2017, s. 55). 2011 ve 2014 yılları arasında Suriyeli sığınmacıların Türkiye'ye geliş sürecini ana akım gazetelerin haber ve köşe yazıları üzerinden inceleyen bir başka çalışmada medyanın ayrımcı dili yeniden ürettiği ve Suriyeli sığınmacılara ilişkin ayrımcı söylemleri meşrulaştırdığı görülmektedir. Suriyeli sığınmacılarla ilgili haber içeriklerini 'tehdit' ve 'ekonomik yük' olarak çerçeveleyen gazeteler, diğer yandan hükümetin sığınmacılara yönelik politikasını örtük biçimde onaylayan bir söylem geliştirmiştir (Doğanay \& Keneş, 2016, s. 177).

Yeni Zelanda'da camide düzenlenen terör saldırısını farklı yayın politikalarından altı gazete üzerinden söylem analizi yöntemi ile incelendiği çalışmada araştırmacılar gazetelerin yaşanan terör saldırısını nasıl haberleştirdiği üzerinde durmuştur. Gazete haberlerinin incelenmesi sonucunda elde edilen bulgularda gazetelerin dil pratiklerinin yayın politikalarını yansıttığı ve terör saldırısını haberleştirirken dini ögeleri kullanmadığı aynı zamanda abartılı ifadelere yer verildiği görülmektedir. Diğer yandan Cumhuriyet ve Sözcü gazeteleri terör saldırısını 'katliam' olarak değerlendirirken, Orta Doğu, Millî Gazete 'Türklük' ve 'milliyetçilik' söylemini vurgulamakta; Yeni Akit ve Yeni Şafak gazeteleri saldırıyı 'Haçıı Terörü' olarak değerlendirerek dini söylemi ön plana çıkarmaktadır (Gölcü vd., 2019, s. 247- 248).

\section{Haberde İdeoloji ve Söylem}

Söylem, dilin kullanımı ve anlamların yapılandırılması (Sözen, 2017, s. 31), dilsel eylemde bulunma biçimi (Devran, 2010, s. 25), aynı zamanda sözel olmayan işaret sistemleri aracılığıyla kurulan toplumsal iletişim ağları (Purvis \& Hunt, 2014, s. 21) olarak tanımlanmaktadır. İdeoloji, birden fazla tanımı olan ve farklı açılardan ele alınan bir kavramdır. İdeolojinin, farklı kavramsal dokularda oluşmuş bir kavram (Eagleton, 2020, s. 17) olması tanım gereği tek ve kapsayıcı bir anlatımının yapılmasını zorlaştırmaktadır.

Anlamlandırma mücadelesi olarak söylem kavramı (Doğanay, 2018, s. 19), toplumsal anlamın üretildiği, şekillendirildiği ve yayıldığı sözü incelemek, açıklamak için kullanılmaktadır (Çınar, 2013 , s. 138). Söylemin içerisinde ideolojiyi barındırması, diğer yandan ideolojinin üretiminde söylemin rolü nedeniyle söylem özellikle eleştirel haber araştırmaları için önemli görülmektedir (Karaduman, 2017, s. 36).

Scholle (1999, s. 268), ideolojinin olumsuz bir yan anlam taşıması sebebiyle söylemden farklı olduğunu belirtmekte, ideolojiyi hakikatin karşıtı ve baskı altında tutan bilgi olarak tanımlamaktadır. İdeoloji, insan davranışının amacını ve bu amaçlara ulaşmanın yolunu tanımlayan prensipler sistemi (Mardin, 2000, s. 18), toplumsal yaşamda anlam, gösterge ve değerlerin üretim sürecidir (Eagleton, 2020, s. 18). Sancar (2020, s. 9), ideolojiyi toplumsal iktidar ilişkileri bağlamında oluşan ve aynı zamanda iktidar ilişkilerinin oluşumunda etkili olan toplumsal düşünce ve anlamlar şeklinde tanımlamaktadır. 


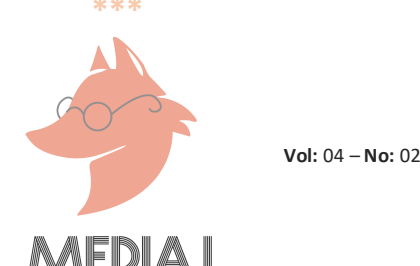

Söylem, dil ve toplumsal göstergebilim biçimlerinin, toplumsal öznelerin, özneler arasındaki iliş̧ilerin ve mücadele alanının oluşturulmasında önemli bir rol oynamaktadır (Purvis \& Hunt, 2014, s. 11). Toplumsal ilişkiler ve süreçlere ilişkin ifadelerin dil kullanımı ile metin ve konuşmalarda kendini göstermesi söylem alanını kapsamaktadır. İdeolojinin maddi ve somut bir biçimde var olması dilin ideoloji tarafından çevrelendiğini göstermektedir (Fairclough, 2020, s. 124).

Ideoloji, söylem yapılarında sahip olunan tutum ve düşüncelerin ifade edilme biçimlerini etkilemektedir. Bu doğrultuda ideolojinin, söylemin üretimi veya yorumlanmasından ayrı düşünülemeyeceği görülmektedir. Diğer yandan ideoloji, tonlama, cümle sözdizimi, sözcük seçimi ve anlamda örtüklük gibi ifade tarzları ile anlamın, bilginin inşasında önemli rol oynamaktadır (Van Dijk, 2001, s. 11). İdeoloji ve söylem arasında güçlü bir ilişki olsa da kavramların birbirinden farkını vurgulayan Purvis \& Hunt (2014, s. 13), söylem kavramının çıkar, güç ve toplumsal ilişkiler içerisindeki bağlantı içeriklerine odaklandığını belirtmektedir. Kısaca söylem, iletişimsel pratiklerin dilsel ve göstergesel (içsel) boyutlarına dikkat çekerken ideoloji, yaşanmış tecrübe, konumlanma biçimi ve çıkar odaklı (dışsal) boyutlara odaklanmaktadır.

Van Dijk (2003), ideolojinin söylem için önemini aktarırken ideolojinin imge, söz dizimi, tonlama, konu, tutarlılık, (ön)varsayımlar, metaforlar gibi anlamı etkileyen yapılarla gündelik ifadeleri etkilediğini belirtmektedir (akt. Karaduman, 2017, s. 40). İdeolojik temelli görüşler söylem yapıları ile ifade edilmekte bir diğer anlamla soyut olan ideoloji somut söyleme dönüşmektedir (Van Dijk, 2020, s. 28). İdeolojilerin kabul görmesi ve varlığını sürdürebilmesi için öznelere ulaşması ve toplumsal pratiklere yansıması gerekmektedir. Bu doğrultuda ideolojik söylem, özneyi ikna etmeye yönelik bir dil ve anlam taşımaktadır. Dilin, sözcüklerin çok anlam, yan anlam yapı özelliği, söz dizimi ve anlatım dizgeleri ideolojiye dışardan gelen bir katkı sağlamaktadır (Çoban, 2020, s. 208).

Söylem ve ideoloji arasındaki ilişkiyi açıklayan Karaduman (2017, s. 35), söylemi anlamın dil içerisinde hareket etmesi olarak tanımlamakta iken ideolojinin ise söz konusu anlamın belirli gruplar veya kişilerin çıkarları doğrultusunda nasıl harekete geçirildiği ile ilgilendiğini belirtmektedir. İdeoloji, söylem yoluyla dolaylı, üstü kapalı bir biçimde tonlama ve duraksama kullanarak farklı yapılarda aktarılmaktadır. Bu şekilde ideoloji kendisini metin veya konuşmalarda anlam ve sözcük biçimi olarak göstermektedir (Van Dijk, 2020, s. 51).

Söylem ve ideoloji arasındaki ilişkinin karşlıklı olduğunu belirten Fairclough (2020, s. 124), söylemin yapılar tarafından biçimlendirildiğini diğer yandan yapıları biçimlendirme ve yeniden üretme noktasında da etkili olduğunu vurgulamaktadır. İdeoloji hem söylenen şeyi hem de söylenme şeklini etkilemektedir. Bu noktada söylem, ideolojiyi aktarma işlevi görmektedir. Söylemin, ideolojileri ifade etme, vurgulama ya da yok sayma yöntemleri açısından sözcüklerin tonlaması, sayfa düzeni, yazı karakteri, görselin yaratacağı etki önemli rol oynamaktadır (Van Dijk, 2020, s. 99).

Toplumsal yaşamın doğal bir parçası olarak kullanılan ideolojiler iktidara, toplumsal hareketlere, egemenlik ve mücadele alanlarına konu olmakta ve yeniden üretilmektedir (Van Dijk, 2020, s. 47). Medya, sahiplik ve çıkar yapısı nedeniyle haber içeriklerini kendi yayın politikasına ve bakış 


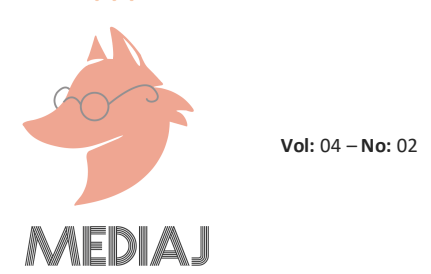

açısına göre inşa etmektedir. Bu doğrultuda farklı gazete ve televizyon kanallarında haberler farklı şekilde sunulmakta ve farklı söylemler içermektedir. Medyanın haber değeri taşıyan olayları kendi ideolojisine göre belirlemesi, yaşanan durumların ön plana çıkarılması veya yok sayılması; kendi ideolojisini yeniden üretmesi ve bu şekilde yaygınlaştırması haberi inşa etme ve sunma biçimini göstermektedir (Devran, 2010, s. 121). Söylem sürecinin bir sonucu olarak ortaya çıkan haber içerikleri farklı kaynak ve görgü tanıklarından gelen bilgiler çerçevesinde yeniden yapılandırılmaktadır. Bu durum mevcut olan söylemin haber inşasına olan etkisini göstermektedir. Haberin içeriği ve iletilmek istenen ideoloji doğrultusunda konu başlı̆ı, sözcük dizimi, haber üslubu kurulmakta iken bütün bu süreç söylemi oluşturmaktadır (Şeker, 2003, s. 103).

Söylem aracılı̆̆ıyla ideoloji, haber içeriklerine yerleştirilerek iletilmektedir. Sözcüklerin, cümlelerin yapısı, akışı, tanımlamalar, ön varsayımlar, istatistiki bilgi ve kanıtlardan yararlanma gibi retorik unsurlar ideolojinin yeniden üretilmesini desteklemektedir (Devran, 2010, s. 166). Medyada haberin başlığını, içeriğini, kullanılan fotoğrafı yani görsel ve sözlü söylemi iktidar ve güç sahibi olan kesim belirlemektedir. Bu doğrultuda iktidar sahipleri medyanın gücünden yararlanarak gücü ve iktidarı meşrulaştırma, yeniden üretme imkânı elde etmektedir. Van Dijk, haber söyleminin egemen söylemden, güç ve iktidar sahibi kurum ve yapılardan ayrı olamayacağını belirtmektedir (İnal, 1996, s. 97). İktidar ve güç ilişkileri bağlamında medya içerikleri görsel ve sözlü söylem kullanılarak yapılandırılmakta ve kamuya iletilmektedir (Van Dijk, 1999, s. 367).

\section{YÖNTEM}

Israil'in Filistinlilere karşı 10 Mayıs tarihinde saldırması ve bu saldııların 21 Mayıs tarihine kadar sürmesi üzerine örneklem 11- 21 Mayıs tarihinde yayınlanan gazeteler ile sınırlandırılmıştır. Çalışmanın örneklemini Al Jazeera, TRT World, Sputnik Haber Ajansı, Al Arabiya ve Haaretz oluşturmaktadır. Haber, ideoloji ve söylem ilişkisini ortaya koymak amacıyla çalışmada incelenen medya kuruluşlarının birbirinden farklı yayın politikasına sahip olmasına dikkat edilmiştir.

Haberin başlı başına söylem olduğunu belirten İnal (1996, s. 22), haber söyleminin içinde oluştuğu bağlamın yani medyanın konumu, güç/iktidar ile olan ilişkileri ve bu ilişkileri sürdürme, meşrulaştırmadaki rolünün sorgulanmasının önemini vurgulamaktadır. Bu çalışmada Al Jazeera, TRT World, Sputnik Haber Ajansı, Al Arabiya ve Haaretz ajans ve gazetelerinin İsrail'in Gazze'ye gerçekleştirdiği saldırıları ele alış biçimi Teun Van Dijk'ın makro ve mikro yapı söylem analizi yöntemi ile incelenmiştir. Makro yapıyı başlıklar, spot, haber girişi ve fotoğrafların yer aldığı tematik yapı, durum veya olayın sunumu, ardalan ve bağlam bilgisi, haber kaynakları ve yorumun bulunduğu şematik yapı oluşturmaktadır (Karaduman, 2017, s. 40). Mikro yapı çözümlemesinde ise sözdizimsel, uyum, kelime seçimlerinin yanı sıra haberin retoriği incelenmektedir. Bu bağlamda söz dizin kuralları, aktif-pasif, kısa- uzun gibi cümle kalıpları tespit edilmektedir. Aynı zamanda kelime seçimleri medya kuruluşunun, gazetecinin ideolojisini, yayın politikasını yansıtması bakımından önemli görülmektedir. Haber içeriğinin retorik bakımından incelenmesi ise haberin inandırıcılık ve güvenirliğini arttırmaya yönelik kıyas, mecaz, abartılı veya küçültücü ifadelerin kullanımını kapsamaktadır (Şeker \& Şeker, 2011, s. 521- 522). 


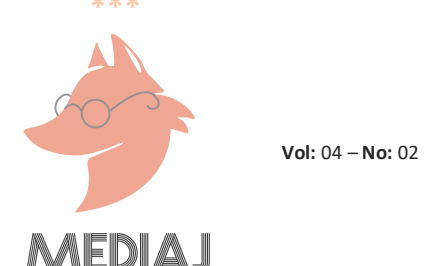

\section{BULGULAR}

\section{AL JAZEERA}

\section{Makro Analiz}

İsrail'in 10 Mayıs günü Gazze'ye saldırması üzerine 11 Mayıs tarihinde Al Jazeera 'İsrail'in Gazze'ye yönelik bombardımanı tırmanırken ölü sayısı 35'e yükseldi' başlığı ile başlayan saldırıyı duyurmuştur. Al Jazeera, İsrail'in gerçekleştirdiği saldırı ve hava bombardımanını, Gazze'de yaşanan olayları kısaca şiddetin bütün boyutlarını sayfasında güncelleyerek, canlı görüntüler paylaşarak okuyucularına ulaştırmıştır. 13 Mayıs gününün sabah saatlerine kadar devam eden içeriklerin güncellenmesi ile İsrail’in uyguladığı terör saldırıları ve Gazze'de yaşanan yıkımı ayrıntıları ile gösterilmektedir.

Haberin girişinde İsrail'in hava saldırılarına Hamas'ın yanıt olarak İsrail'e 200 roket fırlattı̆̆ı ve Tel Aviv'de roket uyarı sirenlerinin çaldığını vurgulanmıştır. Haber fotoğrafında ise tek başına Filistinli bir adamın hava saldırıları üzerine yıkılan binalarda yürüdüğü bir görüntü kullanılmıştır. Haberin devamında İsrail ordusunun Gazze'ye karşı gerçekleştirdiği yoğun hava bombardımanın 2014'teki bombardımandan sonra en yoğun saldırı olduğu belirtilmektedir. İsrail'in hava saldırıları sonucu 10'u çocuk olmak üzere en az 35 Filistinlinin öldüğü 233 kişinin de yaralandığı ifade edilirken, İsrail'de en az 5 kişinin öldüğüne değinilmiştir.

Al Jazeera 12 Mayıs tarihinde Filistinli aktivistlerin dilinden 'ABD, Şiddet Arttıkça İsrail'i durdurmalı' başlığını kullanmış ve aktivistlerin Gazze'ye düzenlenen hava saldırılarının ancak ABD'nin müdahalesi ile son bulacağını düşündüklerini belirtmiştir. Al Jazeera, İsrail'in Filistinlileri Şeyh Cerrah Mahallesinden çıkarmaya çalışması ile başlayan olayların nasıl geliştiğine değinmiş ve Doğu Kudüs'ün yıllardır işgal altında olduğunu belirtmiştir. İsrail polisinin kutsal olan Mescidi Aksa'ya baskın düzenlemesi ve Filistinlilere saldırması sonucu olayların şiddet boyutunu arttırdığını yazan Al Jazeera, Gazze'nin işgal altında olduğunu vurgulamıştır. Aynı zamanda haber metnini destekleyici bir fotoğraf olarak İsrail'in Mescid-i Aksa'ya baskın yaptığı görüntüler kullanılmıştır. Haberde son olarak Filistinli aktivistlerin Biden yönetimine İsrail'i durdurması ve şiddeti önlemesi için yaptığı çağrılara yer verilmiştir.

'İ̧̧gal altındaki Batı Şeria' üst başlığı ile verilen 14 Mayıs tarihli haberde İsrail'in saldırıları sonucu çok sayıda Filistinlinin öldüğü ve İsrail'in şiddetinin giderek arttığı belirtilmektedir. Haberin devamında İsrail'e karşı protesto düzenleyen Filistinlilerin görüşlerine genişçe yer verildiği görülmektedir. 15 Mayıs günü İsrail'in The Associated Press ve Al Jazeera gibi haber kuruluşlarının bulunduğu binaya saldırması üzerine Al Jazeera olayı Filistinli gazetecilerin görüşlerine yer vererek aktarmıştır. Ardından İsrail'in basın kuruluşlarının bulunduğu binaya saldırmasını, şiddet olaylarını haber yapan gazetecileri 'sindirme' girişimi olarak değerlendirmiş ve genel anlamda saldırıların Ramazan ayında yapıldığı üzerinde durulmuştur.

Al Jazeera 15 Mayıs tarihinde “'Bu bir soykırım': Protestocular İsrail'i kınadı, Filistinlileri destekledi" başlığını kullanarak iki dakikalık bir video içeriği paylaşmıştır. Videoda dünyanın farklı 


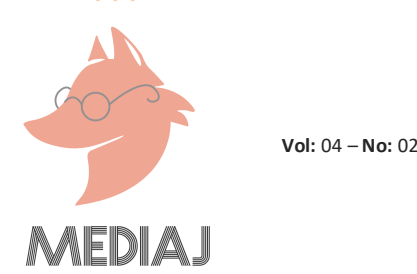

yerlerinden düzenlenen protestoların yanı sıra İsrail'in saldırılarına ilişkin uzman görüşlere ve protestocuların düşüncelerine yer verilmiştir. Ölenlerin sayısının 200'ü aştığı 17 Mayıs tarihinde Al Jazeera, "İsrail İslami Cihad komutanını öldürdü, Gazze'de ölü sayısı 200'ü aştı" başlığını ve İsrail'in hava saldırısı sonucu evini kaybeden Filistinli bir ailenin yıkılmış evlerinin önünde oturduğu bir fotoğraf kullanmıştır. Haberin devamında İsrail savaş uçaklarııın ev, hastane, hükümet binası dahil olmak üzere her yeri vurduğu ve İslami Cihad grubunun üst düzey komutanı Hussam Abu Harbeed'in öldürüldüğü belirtilmektedir.

İsrail saldırılarının devam ettiği 18 Mayıs tarihinde Al Jazeera "Israil güçleri, işgal altındaki Batı Şeria'da Filistinli protestocuyu öldürdü" başlığını kullanarak hava saldırıları sonucu ölenlerin sayısının arttığını ve Gazze'de bir katliamın yapıldığını belirtmektedir. Gerçekleşen saldırılar ile ilgili Filistinlilerin düşüncelerine yer veren Al Jazeera'nin haberin inşasını görgü tanıkları üzerinden kurduğu görülmektedir. 19 Mayıs günü “issrail'in Gazze'deki önemli binaları hedef almasının arkasında ne var?" başlığı ile verilen haberde İsrail'in sivillerin olduğu binalara saldırmasının sebebinin Filistinlilerin kararlılı̆ını zayıflatma girişimi olduğu belirtilmektedir. Haberin devamında İsrail'in 10 Mayıs'tan itibaren hava saldırıları sonucu 184'ten fazla konut, medya kurumlarının da olduğu iş yerlerinin yerle bir edildiği yazıımıştır. 20 Mayıs günü İsrail ve Filistin arasında ateşkesin kabul edilmesi üzerine Al Jazeera, “Ateşkes Devam Ederken Gazze'de Kutlamalar Sürüyor" başlığı ile Mısır'ın aracılık yaptığı ateşkes ile 11 gün süren savaşın bittiğini yazmıştır. İsrail Başbakanı Benjamin Netanyahu'nun ateşkesin kabul edilmesine dair düşüncelerine yer verilmiş ve Hamas'ın ateşkesi doğruladığı yazılmıştır. Al Jazeera haberin devamında 11 günlük süren saldıılar sonucu 65'i çocuk en az 232 kişinin öldürüldüüünü, İsrail'de ise 2 'si çocuk 12 kişinin hayatını kaybettiğini belirtmiştir.

Ateşkesin ardından 21 Mayıs günü Al Jazeera, "Israil ve Hamas, kırılgan ateşkes devam ederken zafer kazandığını iddia ediyor" başığı ile sağlanan ateşkesin İsrail tarafından bozulacağını belirtmektedir. Haberin devamında ateşkese rağmen İsrail polisinin Mescid-i Aksa'ya baskın düzenlediği ve Cuma namazından sonra Filistinlilere göz yaşartıcı gaz kullandığı belirtilmektedir. Ardından İsrail'in 11 günlük saldırısını 'aralıksız bombalama' olarak nitelendirmiştir. Gazze'nin 14 yıllık yıkıcı, yıpratıcı bir şekilde abluka altında olduğunu belirten Al Jazeera, zaten yoksul olan bölgede sanayi, enerji ve tarıma verilen zararı yeniden inşa etmenin maliyetli olacağını vurgulamıştır. Al Jazeera aynı zamanda ateşkesin Hamas'ın zaferi olarak görüldüğünü yazmış, Filistinlilerin kararlılığının övüldüğünü belirtmiştir.

Al Jazeera'nin genel anlamda yaşanan olayları sunma biçimi ele alındığında İsrail'in Gazze'ye yönelik saldırılarını sade bir anlatımla aktardığı ve daha çok yaşanan gelişmelerin sonucunda ölen, yaralanan insanların ve tahrip edilen binaların üzerinde durduğu; ABD'nin İsrail'e saldırıları durdurması için yaptığı çağrıya ve saldırıları protesto etmek amacıyla düzenlenen gösterilere yer verdiği görülmektedir. Bu doğrultuda Al Jazeera'nin, İsrail'in saldırılarına ilişkin aktardığı haberlerde saldırıları daha çok insanlık suçu olarak değerlendirdiği sonucuna ulaşılmaktadır. Al Jazeera İsrail'in saldırılarına ilişkin olayın gelişmesinde etkili olan tarihsel arka plana yer vermemiş, ardalan ve bağlam bilgisi kullanmamıştır. Al Jazeera saldırı olaylarını aktarırken genel bilgiler vermiş, uzman görüşlerin ve halkın ifadelerini çokça kullanmış, eleştirel bir dilden uzak anlatım kullanmıştır. 


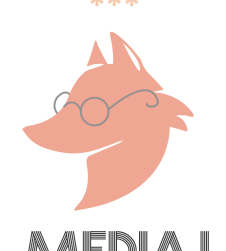

\section{MEDIAJ}

\section{Mikro Analiz}

Al Jazeera, saldırılara ilişkin haberlerde İsrail'in Filistinlilere karşı eylemlerini 'saldırdı 'öldürdü', 'yaraladı' gibi etken yapılı ifadeler ile aktarmış ve uzman görüşü ile bu ifadeleri desteklemiştir. Ölüm ve yaralı oranlarını aktarırken Filistin Sağlık Bakanlığı verileri kullanılmış, Hamas'ın ve Filistinlilerin açıklamalarına, düşüncelerine geniş yer verilmiştir. Genel anlamda saldırılara ilişkin nedensel ifadeler kullanılmamış ve basit, yalın bir anlatım tercih edilmiştir. 16 Mayıs tarihinde Al Jazeera haber girişinde İsrail'in Gazze'ye düzenlediği hava saldırıları sonucu üç binayı yerle bir ettiğini ve en az 42 kişiyi öldürdüğünü yazmıştır.

Al Jazeera, İsrail'in Filistin'e yönelik 11 gün süren saldırılarına ilişkin haberleri aktarırken basit, anlaşılır cümle yapıları tercih etmiş ve olayları haberleştirirken nesnelliğini koruyan bir anlatım sergilemiştir. Ancak Al Jazeera, İsrail'in saldırılarını ve şiddettin sonuçlarını belirtirken 'öldürdü', 'saldırı gerçekleştirdi', 'yerle bir etti' gibi etken yapılı eylemler kullanarak sorumlunun İsrail olduğunu açıkça göstermektedir. Al Jazeera, nesnel bakış açısını koruyarak yalnızca gelişmeleri ve saldırıları haberleştirmiş ancak yer yer özellikle şiddetin oranı arttı̆̆ında İsrail'in hava saldırılarını ve polis şiddetini vurgulamış, 21 Mayıs tarihli haberinde ise saldırıları 'yıkım' olarak nitelendirmiştir.

\section{TRT WORLD}

\section{Makro Analiz}

TRT World 10 Mayıs tarihinde İsrail'in Gazze'ye saldırısını okuyucularına 'Israil Gazze'de 20 Filistinliyi öldürdü, El Aksa baskını yüzlerce kişiyi yaraladı’ başlığı ile duyurmuştur. Haber girişinde İsrail'in hava saldırıları ile 9 çocuk dahil 20 kişinin öldüğü ve 300'ün üzerinde yaralı olduğu belirtilmektedir. TRT World haberinde İsrail'in saldırgan hareketlerinin en üst noktaya çıktığını ve Gazze'de 'en kanlı günlerin' yaşandığını vurgulamıştır. 12 Mayıs tarihli haberde ise hava saldırıları sonucu duman altında olan Gazze şehrinin fotoğrafı paylaşıımış ve başlıkta ölenlerin sayısının 67'ye yükseldiği belirtilmiştir. Haberin devamında İsrail Savunma Bakanı Benny Gantz'ın Gazze'ye hava saldırılarının devam edeceğini ifade ettiği sözlerine yer verilmiştir.

13 Mayıs'ta Mısır'ın İsrail'e gitmesi üzerine TRT World 'Mısır heyeti ateşkes için Tel Aviv'de' başlı̆̆ını kullanmış ve haberin devamında uzman görüşlere yer verilmiştir. 'İsrail'in Gazze'ye acımasız bombardımanı ikinci haftasına girdi' başlı̆ıı ile 17 Mayıs tarihinde saldırı haberlerinin yoğun bir şekilde devam ettiğini duyuran TRT World, kuşatma altındaki Gazze'de ölü sayısının giderek arttığını ve şehrin yaşanamayacak hale geldiğini vurgulamaktadır. Haberin devamında hava saldırıları 2014'ten bu yana gerçekleşen en şiddetli saldırılar olarak tanımlanmıştır.

Hava saldırıları sonucu ağır bir yıkım altında olan Gazze'yi 20 Mayıs'ta fotoğraflarla haberleştiren TRT World hava saldırılarının benzeri görülmemiş bir şekilde devam ettiğini yazmaktadır. Haberin devamında İsrail'in saldırılarından önce şehrin düzenli ve rahat olduğu ancak şu an harabeye döndüğü belirtilmektedir. Haberde aynı zamanda saldırılardan etkilenen insanların düşüncelerine ve yaşadıklarına yer verilmiştir. 


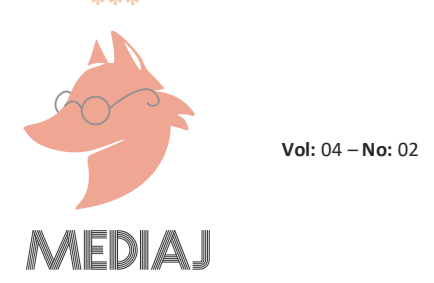

Ateşkesin kabul edildiği 21 Mayıs tarihinde TRT World ateşkesi ‘Gazze'de İsrail ile Filistinli gruplar arasındaki ateşkes yürürlüğe girdi' başlığı ile duyurmuştur. Haberin devamında artan uluslararası baskının sonucu 11 günlük çatışmanın nihayet son bulduğu belirtilmektedir.

Genel anlamda TRT World'ün İsrail'in saldırılarını haberleştirirken ölü ve yaralı sayısı üzerinde durduğu, İsrail'e karşı ağır ithamlardan sakındığı, uzman görüşlere ve konu ile ilgili uzman kişilerin attığı tweetlere yer verdiği görülmektedir. Haber içeriklerinde İsrail'in saldırıları sonucu 'sivil kayıpların' arttığını ve insanların 'ölümcül olaylar' sonucu evlerini terk etmek zorunda kaldığı vurgusu yapılmaktadır. Ardalan ve bağlam bilgisinin bulunmadığı haberlerde yalnızca olayın sürecine ilişkin güncel gelişmeler paylaşıımıştır. Diğer yandan haber içeriklerinde Filistinli gazetecilerin ve halkın saldıııara ilişkin paylaştığı videolara da yer verilmiştir.

Haber içeriğinde kullanılan fotoğraflar ağırlıklı olarak İsrail'in gerçekleştirdiği hava saldırıları ve yıkılan şehir görüntüsüdür. Saldırılar sonucu Gazze'den tahliye edilmek zorunda bırakılan Filistinlilerin görüntülerine de yer verilmiştir. Haberde İsrail'in Gazze Şeridi'nde polis karakollarını vurması, hava saldırıları sonucu Filistinlilerin evsiz kalması ve diğer ülkelerin İsrail'in saldırılarını kınadığı ifadeler kullanılmış, Hamas'ın roket saldırılarına misilleme yaptığını ve Tel Aviv'i vurmakla tehdit ettiğine de kısaca değinilmiştir. Genel olarak haberlerde hava saldırılarının İsrail'in 2014'ten bu yana Filistin'e uyguladığı şiddetli saldırılarının en acımasızı olduğu vurgulanmıştır.

\section{Mikro Analiz}

TRT World İsrail tarafından Gazze'ye 11 gün süren saldırılarını haberleştirirken aktif cümle yapıları tercih etmiş ve 'öldürdü' 'saldırdı' 'yaraladı' gibi etken fiiller kullanmıştır. TRT World'ün haberlerinde doğrudan İsrail'in hedef gösterilmeden 'vahşi saldırı' 'yıkım' 'kurban' ifadeleri ile saldırıları yumuşak bir anlatımla eleştirdiği görülmektedir.

Diğer yandan TRT World saldırı sonucu ölen ve yaralananların sayısını Filistinli sağlıkçı ve uzmanların verilerine kaynak vererek kullanmıştır. TRT World saldırı haberlerinde basit ve sade bir dil kullanmış, gelişmeleri olduğu gibi aktarmıştır. Yan anlam, ima gibi ifadelere yer verilmeyen haber içeriklerinde Müslümanlık, İslam karşıtlığı gibi vurgulara rastlanmamıştır. Terör, terörist ifadelerinden sakınan TRT World, uzmanların açıklamalarına yer vermiş, İsrail'in saldırılarını politikacı ve uzmanların görüşleri temelinde inşa etmiştir.

\section{SPUTNIK HABER AJANSI}

\section{Makro Analiz}

Sputnik İsrail'in 10 Mayıs'taki saldırılarını 'Israil'den Gazze Şeridi'ne hava saldırısı: Netanyahu 'roket saldırılarına çok güçlü karşılık vereceklerini' söyledi' başlığı ile duyurmuştur. Haberin girişinde Filistin Sağlık Bakanlığı kaynak gösterilerek 9'u çocuk 20 kişinin öldüğü bilgisine yer verilmiştir. Haberin devamında İsrail'in Mescid-i Aksa'da Filistinlilere karşı uyguladığı şiddet sonrasında misilleme olarak Hamas'ın İsrail'e roket atışı yaptığı vurgulanmıştır. 


\section{MEDIAJ}

Sputnik, 14 Mayıs tarihinde 'İsrail'in Gazze'ye yönelik hava saldırıları ve Filistinli grupların yanıtı sürüyor' başığı ile Filistinlilerin de saldırılara yanıt verdiğini belirtmekte ve Filistinlilerin gücünü ön plana çıkarmaktadır. Haberin içeriğinde Filistinli grupların roket saldırıları sonucu İsrail'de oluşan hasarlara ait videolara da yer verilmektedir. 16 Mayıs'ta İsrail'in saldırıları devam ederken 'İsrail askerlerinden Batı Şeria'daki Gazze'ye destek gösterilerine müdahale: 6 yaralı' başlığını kullanan Sputnik, İsrail askerlerinin Filistinlilerin gösterilerine acımasızca müdahale ettiğini belirtmektedir. 15 Mayıs tarihinde 'İsrail'in Gazze saldırılarında 145 Filistinli hayatını kaybetti, yaralı sayısı bini geçti' başığı ile 10 Mayıs'tan bu yana 1110 kişinin yaralandığı ifade edilmektedir. Haberde Gazze'deki Filistin Sağlık Bakanlığı Sözcüsü Eşref el-Kudra'nın açıklamaları kullanılmış ve saldırı sonucu 10 ailenin tamamen yok edildiği bilgisine yer verilmiştir.

Hamas'ın siyasi büro yetkililerinden Hüsam Badran'ın röportajına yer verilen 18 Mayıs tarihli haberde 'Hamas'tan Rusya'nın Gazze Şeridi'ndeki gelişmeler karşısındaki tutumuna ilişkin açıklama' başlığı kullanılmıştır. Haberin içeriğinde Filistin'in Gazze Şeridi'nde süren gerginliği azaltmak için uğraşan Rusya'dan memnun olduğu ifade edilmektedir. Haberde Hamas'ın ABD'nin tutumlarını dikkate almadığı ve başta Türkiye, Katar ve Mısır olmak üzere Rusya'nın da desteklerine sevindikleri vurgulanmaktadır. Ateşkesin kabul edildiği 21 Mayıs tarihinde Sputnik, 'Ateşkesin ardından Netanyahu'dan açıklama: Hamas ile denklemi değiştirdik' başlı̆̆ı ile İsrail Başbakanı Benyamin Netanyahu'nun açıklamalarına yer verilmiştir.

Sputnik Haber Ajansının haber içeriklerinde basın açıklamalarından ziyade Hamas'ın faaliyetlerine daha çok yer verildiği görülmektedir. Ayrıca haberlerde Hamas'ın roket atışları ve sayıları vurgulanmaktadır. İsrail'in hava saldıılarının yoğunluğunun ve verdiği tahribatın ağır olduğunu vurgulayan Sputnik, saldırılara ilişkin tarihsel arka plana değinmeden gelişmeleri aktarmıştır.

\section{Mikro Analiz}

Sputnik Haber Ajansı, İsrail'in saldırılarını aktarırken yaşananların terör saldırısı veya insanlık suçu olduğuna vurgu yapmadan basit ve açık bir dil kullanmayı tercih etmiştir. Yaşananlara ilişkin haberlerde saldırılar sonucu hayatını kaybeden insanlar 'öldü' 'yaralandı' gibi edilgen yapılar kullanılarak İsrail'i doğrudan itham eden ifadelerden kaçınılmıştır. Sputnik, haber içeriğinde Rusya'nın Filistin'i desteklemesi ve Gazzelilerin bu konudan duyduğu memnuniyeti vurgulamıştır. Sputnik'in kullandığı haber dilinde İsrail'i hava saldırıları ve gösterdiği şiddet nedeniyle kınadığı söylem ve ifadelere rastlanmamıştır. Sptunik Haber Ajansı İsrail'in saldırılarını doğrudan aktarmış ve saldırıların nasıl başladığına değinmeden şiddet olaylarını sıradanlaştırmıştır.

\section{AL ARABIYA}

\section{Makro Analiz}

10 Mayıs tarihinde İsrail'in Filistin'e saldırısını 'Hamas roketleriyle Kudüs Şiddeti Tırmanıyor, Gazze'de 20 Ölü' başığı ile duyuran Al Arabiya, haberin girişinde Filistinli militanların İsrail'e roket saldırısı gerçekleştirdiğini ve bu şekilde İsrail'i tehdit ettikleri belirtilmektedir. İsrail'in 


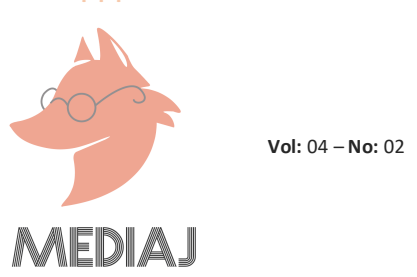

misilleme saldırısı sonucu 9'u çocuk 20 kişinin öldüğü yazılmış ve 'misilleme' kelimesi ile İsrail'in gösterdiği şiddet geri plana atılmıştır. Haberin devamında İsrail ordusunun, Gazze'den sürekli gelen roket atışlarına yalnızca yanıt verdiğini vurgulayan ifadeler tercih edilmiştir. Haber fotoğrafı olarak Gazze'den İsrail'e yapılan roket saldııılarının görseli kullanılmıştır. 11 Mayıs tarihinde ise 'İsrail Saldırıları 26 Filistinlinin Ölümüne Yol Açarken, Hamas Roketleri 2 İsrailliyi Öldürdü' başlığı atılmıştır. 'Öldürdü' ifadesi ile Hamas doğrudan saldırıların sorumlusu olarak gösterilmektedir.

Al Arabiya, 14 Mayıs tarihinde 'İsrail'in Saldırısı Sonucu Batı Şeria'da 6 Filistinli Öldü, Yüzlerce Kişi Yaralandı' başlığını kullanmış ve haberde Filistin Sağlık Bakanlı̆ıı'nın verilerine yer verilmiştir. Haberin devamında İsrail güçlerinin Filistin'in roket atışlarına yanıt olarak bomba saldırılarının devam edeceği ifadeleri vurgulanmaktadır. 15 Mayıs'ta 'Sağlık Görevlileri: İsrail Ordusunun Gazze'ye Hava Saldırısında Aynı Aileden 10 Kişiyi Öldürdü' başlığını kullanılmış ve haberin içeriğinde Gazze'de yaşanan şiddete ilişkin görüntülere yer verilmiştir. Al Arabiya, 16 Mayıs tarihli haberinde Gazze'de yaşananların 10 Mayıs'ta başlayan saldırıların 'en kanlısı' olduğu vurgulanmaktadır. 20 Mayıs'ta ABD Başkanı Biden'ın ateşkes ile ilgili açıklamalarına yer veren Al Arabiya, ateşkesin kabul edilmesinde Mısır'ın oynadığı role değinmiştir.

Genel anlamda Al Arabiya'nın İsrail'in açıklamalarını, İsrail'deki can kayıplarını ve roket saldıılarını ön plana çıkardığı, Filistin'de yaşananlara değindiği, yaralı ve ölü sayılarını kaynaklara atıf yaparak yer verdiği görülmektedir. Al Arabiya, ardalan ve bağlam bilgisine yer vererek İsrail'in 1967 yılında uluslararası tanınırlığı olmayan bir hareketle Kudüs'ü ilhak ettiğini ifade etmiştir. Haber fotoğraflarında ise ağılıklı olarak Filistin'den İsrail'e gönderilen roketlerin görüntüsü kullanılmış, Gazze'de yaşanan saldırıların görselleri tercih edilmemiştir. Al Arabiya'nın yaşanan saldırıları terör saldırısı olarak nitelendirmediği açıkça görülmektedir.

\section{Mikro Analiz}

Al Arabiya'nın, saldırılara ilişkin haberlerde Filistinlilere yönelik doğrudan ithamda bulunmasa da İsrail yetkililerin 'terör örgütü Hamas', 'Gazze'deki terör hedefleri' gibi ifadelerini ön plana çıkardığı görülmektedir. Al Arabiya İsrail'i saldırılardan dolayı suçlayacak net ve imalı ifadelerden kaçınmış, daha çok olaylara ilişkin gelişmelere ve sonuçlara odaklanmıştır. Haberlerde Gazze'de yaşanan şiddeti kınayacak, insanlık, Müslümanlık vurgusuna rastlanmamış olaylar yalnızca sade ve açık bir dille aktarılmıştır. Ayrıca İsrail'in Filistin'e saldırıları 'misilleme', 'karşı saldırı' ve 'yanıt' gibi ifadeler kullanılarak şiddet meşrulaştırılmaya çalışımıştır.

\section{HAARETZ}

\section{Makro Analiz}

Haaretz gazetesi 10 Mayıs tarihinde İsrail'in Gazze'ye saldırısını 'Kudüs Çatışmaları: Yahudi Yürüyüşü Gazze'deki Roket Ateşinden Sonra İptal Edildi' başlı̆ı ile okuyucularına duyurmuştur. Haberin içeriğinde Yahudi ve Araplar arasında devam eden çatışmaların şehrin en kutsal yerlerinden olan Mescid'i Aksa'da Ramazan ayında arttığı belirtilmektedir. Filistinli Müslümanların Cuma namazına gelmesi ile İsrail polisinin şiddet uyguladığı ve çatışmaların 
,

Vol: $04-$ No: 02

başladığı vurgulanmaktadır. Diğer yandan Hamas'ın roket atışları sonucu İsrail'de Kudüs Günü kutlamalarının iptal edildiği belirtilmektedir.

13 Mayıs tarihinde Haaretz, Hamas'ın roket saldırıları nedeniyle 7 kişinin öldüğünü belirtmektedir. Haber fotoğrafında ise Hamas'ın roket saldırısı sonucu İsrail'in savunma sistemlerinde Demir Kubbenin fotoğrafı kullanılmıştır. Haberin devamında İsrail ve Hamas arasındaki çatışmaların 2014'ten bu yana en şiddetli gününü yaşadığı vurgulanmaktadır. Haaretz, Filistin yerine Hamas'ı kullanmayı tercih etmiş, haber içeriğinde de Filistin'den yapılan saldırılar için 'Filistinli militanlar' öznesini kullanmıştır. 15 Mayıs'ta 'Gazze'de Alevlenme, Tel Aviv'de Ağır Roketler' başlığı ile Hamas'ın roket saldırıları öne çıkarılmaktadır. Ardından Netanyahu'nun Filistin'e karşı saldırıların 'gerekli olduğu sürece' devam edeceğini garanti ettiği sözlerine yer verilmiştir. Haberin devamında İsrail'in Gazze'ye hava saldırısı gerçekleştirdiği ancak kara işgalinde bulunmadığı vurgulanarak buna rağmen 'Gazzeli militanların' İsrail'e 2300' den fazla roket fırlattığı belirtilmektedir.

Haaretz, saldırı şiddetinin arttığı 16 Mayıs tarihinde 'Son Alevlenmede Gazze'nin En Ölümcül Gecesinde 40'tan Fazla Ölü; İsrail'de Ölü Sayısı 10'a Çıktı' başlı̆ı ile Gazze'de 'en kanlı gece'nin yaşandığını belirtmektedir. Haberin devamında Filistinli yetkililerin verileri kaynak gösterilerek İsrail'in saldırıları sonucu ölen ve yaralanan kişilerin sayısı da paylaşılmıştır. 18 Mayıs tarihinde 'İsrailli Yetkililer, Roket Saldırıları Devam Ederken Gazze'de Ateşkesin 'Günler İçinde' olmasını bekliyorlar' başlığı kullanılarak İsrail'in ateşkes umudu taşıdığı belirtilmektedir. Haberin devamında Biden ve Almanya'nın ateşkes çağrısında bulunduğu ifade edilerek her iki tarafta da ölü sayısının arttığı vurgulanmıştır.

Ateşkese yaklaşıldığı 20 Mayıs tarihinde Hamas üst düzey yetkilisinin sözlerine yer verilen başlıkla yayınlanan haberde Filistin'in Mescid-i Aksa kurtarılana kadar mücadeleye devam edeceği belirtilmektedir. Haberin devamında Mısır'ın arabuluculuğu ile 2014 yılından bu yana yaşanan en kanlı günlerin son bulacă̆ı ifade edilmektedir. Haberde Filistin saldırılarının 12 kişinin 'ölümüne yol açtığı' ifadesi kullanıımıştır.

Haaretz gazetesinin İsrail'in Filistin'e saldırıları genel anlamda değerlendirildiğinde Filistin'de yaşanan saldırılara yer verdiği ancak olaylara ağırlıklı olarak İsrail yanlısı politikadan yaklaştığı, saldııları insanlık suçu olarak dahi değerlendirmediği, ölü ve yaralı sayısını belirtmekle yetindiği, haber fotoğraflarında İsrail'e atılan roketlerin görüntüsünü kullanarak İsrail'in Filistin'e saldırıları görmezden geldiği dikkat çekmektedir.

\section{Mikro Analiz}

Haaretz, İsrail saldırıları ve sonuçlarını aktarırken sorumluyu göstermeden Filistinliler için 'öldü' 'yaralandı' 'binalar tahrip edildi' ifadelerini kullanmıştır. Diğer yandan Hamas tarafından atılan roket saldırıları sonucu ölen ve yaralanan kişiler için 'israil'de öldürülenlerin 9'u sivildi' gibi Filistin'i merkezine alan etken ifadelere yer verilmiştir. Haaretz gazetesi neredeyse her haberinde Filistin'den gönderilen roketlerin sayısına vurgu yapmakta ve karşı saldırı sonucu ölen İsraillilere ilişkin ayrıntıları açıklamaktadır. Haaretz gazetesi, İsrail'in saldırılarını iki taraf arasında gelişen 'çatışma' olarak değerlendirerek şiddetin sorumluluğuna Filistin'i de ortak etmektedir. Genel anlamda Haaretz söylemlerinde saldırılara ilişkin hem İsrail'i hem de Filistin'i 
vurgulamakta ancak Gazze'de yaşanan gelişmeleri sıradan bir şekilde aktarmaktadır.

\section{SONUÇ}

İsrail'in Filistinlilere karşı uyguladığı süregelen saldırıların Ramazan ayında şiddet boyutunu arttırması ve 10 Mayıs tarihinde hava bombardımanına dönüşmesi ile yaşananlar dünya basınında geniş bir şekilde yer almıştır. Bu çalışmada 10 Mayıs'ta başlayan ve 21 Mayıs tarihli ateşkese kadar devam eden süreçteki saldırıların dünya basını tarafından nasıl ele aldığı incelenmiştir. Bu doğrultuda Al Jazeera, TRT World, Sputnik Haber Ajansı, Al Arabiya ve Haaretz medya kuruluşları seçilerek söylem analizi yöntemi ile saldırılara ilişkin bulgular ortaya konmuştur.

Haber, söylem ve ideoloji çerçevesinde farklı yayın politikalarına sahip medya kuruluşlarının içerikleri incelendiğinde İsrail'in Filistin'e saldırması ile ilgili gelişmelere geniş oranda yer verildiği görülmektedir. Çalışmada ele alınan basın kuruluşları saldırıları takip ederek internet sayfalarında son gelişmeleri güncel bir şekilde paylaşmıştır. Al Jazeera haber içeriğinde, İsrail tarafından Filistin'e karşı bugüne kadar gerçekleştirilen saldırıların en yoğun saldırı olduğunu vurgulamıştır. Ayrıca İsrail saldırılarının Ramazan ayında yapılması ve Cuma namazı çıkışında Filistinlilere göz yaşartıcı gaz sıkılması Al Jazeera tarafından altı çizilerek belirtilmiş ve dolaylı olarak İslam'ın hedef alındığı gösterilmiştir. Genel anlamda Al Jazeera'nin İsrail'in gerçekleştirdiği saldırıları haberleştirirken Filistin'i destekleyen bir dil kullandığı görülmektedir. TRT World, İsrail'in Gazze'ye saldırılarını 'en kanlı günler' olarak nitelendirmekte iken Hamas'ın roket saldırıları ile karşılık vererek Filistin'i savunduğuna vurgu yapmıştır.

Sputnik Haber Ajansı haberlerinde diğer medya kuruluşlarından farklı olarak Hamas'ın karşı saldırı olarak roket atışlarının İsrail'de yarattığı tahribatın görsellerine yer vermiştir. Haber içeriklerinde Rusya'nın İsrail- Filistin gerginliğini azaltmadaki başarısına yer verilerek Hamas'ın ABD'den ziyade Rusya'nın görüşlerini dikkate aldığı vurgulanmıştır. Ayrıca Hamas'ın basın açıklamalarına geniş yer veren Sputnik Haber Ajansı'nın İsrail'in saldıılarını terör saldırısı olarak değerlendirmediği ve gelişmeleri tamamen siyasal bir temel üzerine inşa ettiği görülmektedir. Al Arabiya, saldırının başladığı tarihte Filistinlileri militan olarak nitelendirerek İsrail'in misillemede bulunduğunu belirtmiş ve İsrail'in saldırılarını meşrulaştırıcı söylemler kullanmıştır. Al Arabiya'nın incelenen haber içeriklerinde Hamas'ın roket atışı sonucu i̇srail'de ortaya çıkan hasarları ön plan çıkardığı ve İsrail'in yalnızca rokete karşılık verdiğini vurguladığı görülmektedir. Al Arabiya, Filistin'de yaşananları sorumlu göstermeden sade bir dille aktarmayı tercih etmiştir. Haaretz ise haber içeriğinde Filistin yerine Hamas ve militan ifadelerini kullanmayı tercih etmiştir. Bu şekilde İsrail yayın organının Filistin vatandaşlarını ayırt etmeden terörist olarak değerlendirdiği görülmektedir. Haberlerde Hamas tarafından İsrail'e atılan roket sonucu ölen ve yaralananların sayısı ön plana çıkarılmış ancak Filistin'de yaşanan kayıplara kısaca değinilmiştir.

Bu çalışmada incelenen birbirinden farklı 5 medya kuruluşunun İsrail- Filistin gelişmelerini aktarırken farklı yönleri üzerinde durduğu veya ön plana çıkardığı görülmektedir. Haber, ideoloji ve söylem çerçevesinde incelenen haber içeriklerinde basın kuruluşlarının İsrail saldırılarını doğrudan 'terör saldırısı' olarak nitelendirilmediği, tarafları itham edecek söylem ve ifadelerden kaçınıldığı, yaşanan saldırılara ilişkin gelişmeleri görgü tanıkları ve uzman görüşler temelinde inşa 
edildiği, İsrail- Filistin sorununun tarihsel arka planının görmezden gelindiği sonucuna ulaşılmıştır. İncelenen haberler doğrultusunda işlenen insanlık suçu ve terör olaylarında da medya kuruluşunun ideoloji temelli haber ve söylem inşasını gerçekleştirdiği, medya kuruluşlarındaki ideolojinin izlerinin haber dilinde ve görselinde bulmanın kolay olduğu görülmektedir.

\section{KAYNAKÇA}

Arslan, D. (1998). Aile içinde kadına yönelen şiddet ve istanbul kadın misafirhanesi, [Yayınlanmamış Yüksek Lisans Tezi]. İstanbul Üniversitesi.

Avşar, Z. (2017). Internet çağında medya, terör ve güvenlik. TRT Akademi Olağanüstü Dönemlerde Yayıncılık, 2(3), 117-132.

Bassiouni, C. M. (1982). Media coverage of terrorism: the law and the public. Journal of Communication, 32(2), 128-143. https://doi.org/10.1111/j.1460-2466.1982.tb00501.x

Cirhinlioğlu, Z. (2004). Terör ve toplum. Gündoğan Yayınları.

Çakır, H. (2007). Gazeteciliğe giriş. Tablet Yayınları.

Çelenk, S. (2010). Ayrımcılık ve medya. B. Çaplı ve H. Tuncel (Ed.), Televizyon Haberciliğinde Etik içinde (s. 211-228.). Fersa.

Çınar, M. (2013). Habercilik ve nefret söylemi. M. Çınar (Ed.), Medya ve nefret söylemi: kavramlar, mecralar, tartışmalar (s. 137-155). İstanbul: Hrant Dink Vakfı Yayınları.

Çoban, B. (2020). Söylem, ideoloji ve eylem: iktidar ve muhalefet arasındaki mücadeleyi çözümleme denemesi, Söylem ve ideoloji, B. Çoban ve Z. Özarslan (Ed.), (3. Baskı). (s. 199-233). Su Yayınları.

Devran, Y. (2010). Haber Söylem Ideoloji. Başlık Yayın Grubu.

Doğanay, Ü. (2018). Ayrımcılık, söylem ve medya ayrımcılığın yüzleri (Der. Ü. Doğanay), (s. 16-39). Şen Matbaa.

Doğanay, Ü. ve H. Ç. Keneş (2016). Yazılı basında Suriyeli 'mülteciler': ayrımcı 143 söylemlerin rasyonel ve duygusal gerekçelerinin inşası. Mülkiye Dergisi, 40(1), 143-184.

Durur Küçük, E. (2017). Medyada şiddetin bir başka yüzü: 'doktora saldırı' haberleri, Atatürk Iletişim Dergisi, 14, 45-60.

Eagleton, T. (2020). Ideoloji. (Çev. M. Özcan), Ayrıntı Yayınları.

Fairclough, N. (2020). Dil ve ideoloji. Söylem ve ideoloji, B. Çoban ve Z. Özarslan (Ed.), (3. Baskı), İstanbul: Su Yayınları, 121-134. 


\section{MEDIAJ}

Gölcü, A., Bal, E. \& Karadeniz, B. (2019). Dil ve söylem pratiklerini haber metinlerinde aramak: Yeni Zelanda terör saldırısı örneği. RumeliDE Dil ve Edebiyat Araştırmaları Dergisi, (17), 220-251.

Gümüş, A. (2006). Şiddet Türleri, Eğitim Sen Toplumsal Bir Sorun Olarak Şiddet Sempozyumu, Ankara, Türkiye, 20-21 Mayıs 2006, 13- 35.

İnal, M. A. (1996). Haberi okumak. Temuçin Yayınları.

Karaduman, S. (2017). Eleştirel söylem çözümlemesinin eleştirel haber araştırmalarına katkısı ve sunduğu perspektif. Maltepe Üniversitesi Illetişim Fakültesi Dergisi, 4(2), 31-46.

Keneş, Ç. H. (2014). Yeni ırkçı söylemlerin eklemli niteliği ve medyanın işlevi. Ankara Üniversitesi SBF Dergisi, 69(2), 407-433.

Mardin, Ş. (2000). Ideoloji (6. Baskı). İletişim Yayınları.

Michaud, Y. (1994). Şiddet, (C. Muhtaroğlu Çev.). İletişim Yayınları.

Öner, Y. (2004). Şiddetin topolojisi kitap değerlendirmesi. On Dokuz Mayıs Üniversitesi Ilahiyat Fakültesi Dergisi, 47, 605-615.

Palabıyıkoğlu, R. (1997). Medya ve şiddet. Kriz Dergisi, 5(2), 123-126.

Purvis, T. \& Hunt, A. (2014). Söylem, ideoloji, söylem, ideoloji, söylem, ideoloji... Moment Dergi, 1(1), 9- 36. Yayınevi.

Riches, D. (1989). Antropolojik açıdan şiddet, (D. Hattatoğlu Çev.). İstanbul: Ayrıntı

Sancar, S. (2020). İdeolojinin serüveni yanlış bilinç ve hegemonyadan söyleme (4. Baskı). Imge Kitabevi.

Sholle, J. D. (1999). Eleştirel çalışmalar: ideoloji teorisinden iktidar/bilgiye. Medya iktidar ideoloji, (Çev. M. Küçük), 2. Basım, Ankara: Bilim ve Sanat Yayınları Ark, 167-297.

Sözen, E. (2017). Söylem belirsizlik, mübadele, bilgi/güç ve refleksivite. Profil Kitap.

Şeker, M. (2003). Haber söylemi içinde yapılandırılmış örtülü nesnellik ihlalleri. Selçuk iletişim, 4(2), 100- 113.

Şeker, T. N. ve Şeker, M. (2011). Televizyon haberlerinde söylem: 29 Mart 2009 yerel seçimler örneği. Selçuk Üniversitesi Türkiyat Araştırmaları Dergisi (30), 515-522.

Trend, D. (2008). Medyada şiddet efsanesi eleştirel bir giriş, (G. Bostancı Çev.). İstanbul: Yapı Kredi Yayınları. 


\section{MEDIAJ}

Tunçay, E. (2017). Medyada nefret söylemi: Ankara patlaması örneği. Marmara Iletiş̧im Dergisi, 27, 41-62.

Uysal, M (2006, Mayıs, 20-21). Medya ve şiddet, [Sözlü sunum]. Eğitim Sen Toplumsal Bir Sorun Olarak Şiddet Sempozyumu, Ankara, Türkiye.

Van Dijk, T. A. (1999). Söylemin yapıları ve iktidarın yapıları. Medya iktidar ideoloji, (Çev. M. Küçük), 2. Basım, Ankara: Bilim ve Sanat Yayınları Ark, 331-377.

Van Dijk, T. A. (2001). Discourse, Ideology and context. Folia Linguistica, (1)2, 11-40.

Van Dijk, T. A. (2020). Söylem ve ideoloji çok alanlı bir yaklaşım., B. Çoban ve Z. Özarslan (Ed.) Söylem ve ideoloji (3. Baskı) (s. 15-101). Su Yayınları.

Zorlu, Y. (2016). Medyadaki şiddet ve etkileri. Humanities Sciences, 11(1), 13-32. 